\title{
Atelectasis as a complication of acute bronchiolitis in the neonate
}

Anja Korošec, Jana Lozar Krivec, Mojca Grošelj Grenc

\section{Izvleček}

Izhodišča. Akutni bronhiolitis je eden glavnih vzrokov za hospitalizacijo otrok, mlajših od dveh let. Atelektaza, neujemanje ventilacije s perfuzijo in bakterijske superinfekcije so zapleti, ki zahtevajo neinvazivno ali invazivno predihavanje. Opredeliti smo želeli dejavnike, ki vplivali na pojavnost atelektaze pri novorojenčkih z akutnim bronhiolitisom. Bolniki in metode. $V$ retrospektivno kohortno analizo smo vključili novorojenčke z akutnim bronhiolitisom, ki so bili od oktobra 2017 do marca 2018 hospitalizirani na Kliničnem oddelku za neonatologijo UKC Ljubljana. Razdelili smo jih $v$ dve skupini: s pridruženo atelektazo ali brez. Skupini smo primerjali glede na anamnestične, klinične in laboratorijske dejavnike.

Rezultati. Zdravili smo 29 novorojenčkov z akutnim bronhiolitisom, $8 \mathrm{~s}$ pridruženo atelektazo. Novorojenčki s pridruženo atelektazo so dlje potrebovali dodatek kisika $v$ vdihanem zraku $(p=0,01)$ in so bili večkrat neinvazivno in invazivno predihavani $(p=0,017)$. Večkrat so bili zdravljeni $z$ antibiotiki $(p=0,004)$ in imeli radiološke znake pljučnice $(p=0,008)$. Skupini se nista razlikovali v deležu nedonošenosti, okužbe z respiratornim sincicijskim virusom (RSV), porodni teži in spolu.

Zaključki. Novorojenčki z bronhiolitisom in atelektazo so imeli pogosteje bakterijsko superinfekcijo in pljučnico.

Ključne besede: akutni bronhiolitis, atelektaza, novorojenček, dejavnik tveganja.

\begin{abstract}
Background. Acute bronchiolitis is one of the main reasons for the hospitalisation of children under two years of age. Atelectasis, ventilation-perfusion mismatch, and bacterial superinfection can lead to non-invasive or invasive ventilation support. We aimed to identify the risk factors for the development of atelectasis in newborns with acute bronchiolitis. Patients and methods. The retrospective cohort analysis included neonates with acute bronchiolitis who were hospitalised at the Department of Neonatology, Division of Paediatrics, University Medical Centre Ljubljana in the period from October 2017 to March 2018. The patients were divided into two groups: neonates with associated atelectasis and without. We reviewed their medical history, clinical, and laboratory indicators.

Results. We treated 29 neonates with acute bronchiolitis, 8 had associated atelectasis. The group of neonates with atelectasis required supplementary oxygen for a longer period ( $p=0.01)$ and more frequently non-invasive and/or invasive ventilation support $(p=0.017)$. They were more often treated with antibiotics $(p=0.004)$ and radiological signs of pneumonia were more frequently seen $(p=0.008)$. Prematurity, birth weight, male gender, and respiratory syncytial virus (RSV) infection were not identified as risk factors for atelectasis. Conclusions. Neonates with acute bronchiolitis and atelectasis were more likely to have bacterial superinfection and pneumonia.
\end{abstract}

Key words: acute bronchiolitis, atelectasis, newborn, risk factor. 


\section{Uvod}

Akutni bronhiolitis je posledica virusne okužbe spodnjih dihal pri otrocih v prvih dveh letih življenja. Je eden pogostejših vzrokov dihalne stiske pri novorojenčkih. Najpogostejši, v brisu nazofarinksa dokazan patogen je respiratorni sincicijski virus (RSV). Največ bolnikov ugotavljamo $v$ zimskih mesecih. Bolezen je samoomejujoča, zato je zdravljenje zgolj podporno in simptomatsko. Ob manjšem tekočinskem vnosu bolniki potrebujejo tekočinsko zdravljenje, pri hipoksemiji pa zdravljenje s kisikom. Opravimo lahko bronhodilatatorni test $s$ salbutamolom in ob pozitivnem izvidu nadaljujemo $z$ inhalacijami salbutamola. Bolezen s hujšim potekom zahteva neinvazivno ali invazivno predihavanje (1-4).

Virusna okužba povzroči odmrtje epitelnih celic bronhiolov, kopičenje vnetnih celic, edem sluznice in povečano nastajanje sluzi, kar povzroči zaporo svetline bronhiolov, ujetje zraka in hiperinflacijo prizadetih delov pljuč. Vsrkanje ujetega zraka distalno od zapore vodi v nastanek lokalne atelektaze in ventilacijsko-perfuzijsko nesorazmerje. Med pogoste zaplete bronhiolitisa pri novorojenčkih uvrščamo še bakterijsko superinfekcijo, premore dihanja in dihalno odpoved. Največ zapletov pričakujemo pri nedonošenčkih, novorojenčkih s kronično pljučno boleznijo, novorojenčkih s prirojeno srčno napako, novorojenčkih z živčno-mišično boleznijo in pri novorojenčkih z imunsko pomanjkljivostjo (2-4).

Ker smo v sezoni $2017 / 2018$ pri kar $30 \%$ na Kliničnem oddelku za neonatologijo hospitaliziranih novorojenčkih z bronhiolitisom ugotavljali pridruženo atelektazo, smo $v$ retrospektivnem pregledu bolnikov želeli analizirati dejavnike, ki bi lahko vplivali na potek bolezni in na pojavnost zapletov.

\section{Bolniki in metode}

$\checkmark$ raziskavo smo vključili vse novorojenčke, ki so bili zaradi akutnega bronhiolitisa od oktobra 2017 do marca 2018 hospitalizirani na Kliničnem oddelku za neonatologijo.

Novorojenčke smo retrospektivno poiskali v računalniškem sistemu ThinkMed na osnovi naslednjih odpustnih diagnoz: Akutni bronhiolitis, ki ga povzroča RSV (ICD-10, J21.0), Akutni bronhiolitis, neopredeljen (ICD10, J21.9) in Akutni bronhiolitis, ki ga povzročajo drugi mikroorganizmi (ICD-10, J21.8). V dokumentaciji smo poiskali anamnestične, klinične in laboratorijske podatke o novorojenčkih (datum rojstva, diagnoze, povzročitelj, zdravljenje $z$ antibiotikom, vrednost vnetnih kazalnikov (število levkocitov, delež nevtrofilnih granulocitov, delež paličastih nevtrofilnih granulocitov, C-reaktivni protein (CRP)), število dni zdravljenja s kisikom, uporaba neinvazivnega predihavanja, potreba po premestitvi $v$ enoto intenzivne terapije oz. potreba po invazivnem predihavanju, pozitivne kužnine, pridružene bolezni, kajenje matere, najvišja izmerjena telesna temperatura, gestacijska starost, porodna teža, ocena po Apgarjevi in pridružena atelektaza ali pnevmotoraks). Bolnike smo razvrstili v dve skupini, tj. novorojenčke s pridruženo atelektazo in novorojenčke brez nje.

Podatke smo statistično obdelali s programom SPSS (Statistical Package for the Social Sciences, version 20.0; SPSS Inc., Chicago, IL, USA). Za numerične spremenljivke smo izračunali srednjo vrednost in razpon, ker so bile večinoma asimetrično porazdeljene. Vrednosti med skupinama smo preverjali z Mann-Whitneyjevim testom. $Z a$ atributivne spremenljivke smo uporabili test $\chi^{2}$. Kot statistično značilne smo opredelili rezultate $z$ vrednostjo $p$, manjšo od $0,05(p<0,05)$.

\section{Rezultati}

Od oktobra 2017 do marca 2018 se je na Kliničnem oddelku za neonatologijo zdravilo 29 novorojenčkov z odpustno diagnozo akutni bronhiolitis. Na rentgenogramu pljuč je bila atelektaza vidna pri osmih novorojenčkih. Pnevmotoraksa ni imel noben novorojenček. Osem novorojenčkov je imelo radiološke znake pljučnice. Anamnestične, demografske, klinične in laboratorijske podatke pri obeh skupinah prikazujemo v Tabeli 1. Najpogostejši virusni povzročitelj v obeh skupinah je bil respiratorni sincicijski virus (RSV) (Slika 1). Bakterijske povzročitelje prikazujemo v Tabeli 1.

\section{Razpravljanje}

Atelektaza je pomemben zaplet akutnega bronhiolitisa. Poglobi namreč ventilacijsko-perfuzijsko nesorazmerje, ki je poglaviten razlog hipoksemije otrok z akutnim bronhiolitisom. Čeprav patofiziološki mehanizem nastanka atelektaze poznamo, so dejavniki tveganja za njen nastanek slabo raziskani. Ker pojav atelektaze običajno vodi v poslabšanje kliničnega stanja, smo predvidevali, da bodo dejavniki tveganja za nastanek atelektaze podobni dejavnikom tveganja za hud potek bronhiolitisa. Naši rezultati ne potrjujejo, da so nedonošenost, nizka porodna teža, moški spol in okužba z RSV dejavniki tveganja za nastanek atelektaze, medtem ko kajenja zaradi omejitev raziskave nismo uspeli ovrednotiti. Glede na rezultate raziskave so imeli novorojenčki z atelektazo večkrat pridruženo pljučnico in so pogosteje prejemali antibiotično zdravljenje. Rezultati tudi potrjujejo, da je bil pri novorojenčkih z atelektazo potek bolezni težji, saj so pogosteje potrebovali neinvazivno in invazivno ventilacijsko podporo, čas zdravljenja s kisikom pa je bil daljši. 


\begin{tabular}{|c|c|c|c|}
\hline Kazalnik & $\begin{array}{l}\text { Novorojenčki } \\
\text { z atelektazo }\end{array}$ & $\begin{array}{l}\text { Novorojenčki } \\
\text { brez atelektaze }\end{array}$ & $\mathrm{p}$ \\
\hline število novorojenčkov (N) & 8 & 21 & \\
\hline $\begin{array}{l}\text { spol }(N) \\
M\end{array}$ & $5(62,5 \%)$ & $10(47,6 \%)$ & 0,198 \\
\hline $\begin{array}{l}\text { GS (tedni) } \\
\text { mediana (razpon) }\end{array}$ & $40(32-41)$ & $39,4(36-41)$ & 0,232 \\
\hline $\begin{array}{l}\text { porodna teža (g) } \\
\text { mediana (razpon) }\end{array}$ & $3320(1580-3950)$ & $3540(2590-4760)$ & 0,178 \\
\hline NR z GS $<37$ tednov $(\mathrm{N})$ & $2(25 \%)$ & $2(9,5 \%)$ & 0,297 \\
\hline $\begin{array}{l}\text { kajenje staršev (N) } \\
\text { podatki na voljo } \\
\text { da }\end{array}$ & $\begin{array}{l}5 \\
3(60 \%)\end{array}$ & $\begin{array}{l}6 \\
3(50 \%)\end{array}$ & \\
\hline $\begin{array}{l}\text { najvišja izmerjena TT }\left({ }^{\circ} \mathrm{C}\right) \\
\text { mediana (razpon) }\end{array}$ & $37,25(37-38,8)$ & $37,5(36,5-38,6)$ & 0,414 \\
\hline $\begin{array}{l}\text { zdravljenje s kisikom (dnevi) } \\
\text { mediana (razpon) }\end{array}$ & $7(5-13)$ & $5(0-11)$ & 0,01 \\
\hline $\begin{array}{l}\text { najvišji izmerjeni } \mathrm{pCO}_{2}(\mathrm{kPa}) \\
\text { mediana (razpon) }\end{array}$ & $7,64(6,43-8,32)$ & $7,00(3,37-9,84)$ & 0,418 \\
\hline$N P(N)$ & $7(87,5 \%)$ & $6(28,5 \%)$ & 0,003 \\
\hline $\begin{array}{l}\text { način NP }(\mathrm{N}) \\
\text { nCPAP } \\
\text { nBIPAP } \\
\text { ZVP }\end{array}$ & $\begin{array}{l}6(75 \%) \\
4(50 \%) \\
2(25 \%)\end{array}$ & $\begin{array}{l}3(14,3 \%) \\
1(4,8 \%) \\
4(19 \%)\end{array}$ & \\
\hline $\mathrm{IP}(\mathrm{N})$ & $2(25 \%)$ & 0 & 0,017 \\
\hline RTG znaki pljučnice (N) & $5(62,5 \%)$ & $3(14,3 \%)$ & 0,008 \\
\hline antibiotično zdravljenje (N) & $7(87,5 \%)$ & $6(28,5 \%)$ & 0,004 \\
\hline $\begin{array}{l}\mathrm{CRP} \text { (mg/l) } \\
\text { mediana (razpon) }\end{array}$ & $25(5-147)$ & $5(5-116)$ & 0,216 \\
\hline $\begin{array}{l}\text { število levkocitov (x 109/l) } \\
\text { mediana (razpon) }\end{array}$ & $10,25(6,7-19,5)$ & $11,5(7,1-25,7)$ & 0,962 \\
\hline $\begin{array}{l}\text { delež NG (\%) } \\
\text { mediana (razpon) }\end{array}$ & $36(28-59)$ & $33(11-63)$ & 0,824 \\
\hline $\begin{array}{l}\text { delež PNG (\%) } \\
\text { mediana (razpon) }\end{array}$ & $2(0-14)$ & $2(0-18)$ & 0,71 \\
\hline
\end{tabular}

TABELA 1. ANAMNESTIČNI, DEMOGRAFSKI, KLINIČNI IN LABORATORIJSKI PODATKI PRI NOVOROJENČKIH Z ATELEKTAZO IN PRI NOVOROJENČ́KIH BREZ NJE.

Legenda: CRP - C-reaktivni protein; GS - gestacijska starost; IP - invazivno predihavanje; M - moški; N - število; NG - nevrofilni granulociti; NP - neinvazivno predihavanje; NR - novorojenčki; nBIPAP - neinvazivno vzdrževanje stalnega pozitivnega tlaka $v$ dihalnih poteh na dveh ravneh; nCPAP - neivazivno vzdrževanje stalnega pozitivnega tlaka v dihalnih poteh; PNG - paličasti nevtrofilni granulociti; RTG - radiološki; TT - telesna temperatura; ZVP - zdravljenje z visokopretočnim kisikom

TABLE 1. ANAMNESTIC, DEMOGRAPHIC, CLINICAL AND LABORATORY DATA IN THE GROUP OF NEWBORNS WITH AND WITHOUT ATELECTASIS.

CRP - C-reactive protein; GS - gestational age; IP - invasive respiratory support; M - male; N - number; NG neutrophil granulocytes; NP - non-invasive respiratory support; NR - neonates; nBIPAP - non-invasive Bi-level Positive Airway Pressure respiratory support; nCPAP - non-invasive continuous positive airway pressure respiratory support; PNG - immature neutrophil granulocytes; RTG - radiological; TT - body temperature; ZVP - Treatment with high-flow nasal cannula oxygen.

RSV je eden glavnih povzročiteljev okužb dihal v prvem letu življenja (60-80\%), sledijo mu rinovirus (14-30\%), bokavirus (14-15\%), redkeje metapnevmovirus, enterovirus, koronavirus in virus gripe (2-8). $V$ obeh skupinah novorojenčkov je bil najpogostejši povzročitelj RSV, razlika pa ni bila statistično značilna. Poleg RSV sta bila $v$ bistveno manjšem številu dokazana še rinovirus in enterovirus.

$\checkmark$ primerjavi $z$ donošenimi novorojenčki z bronhiolitisom pri nedonošenčkih kot tudi za gestacijsko starost lahkih novorojenčkih pričakujemo težjo obliko bolezni (2). Nedonošenčki so bolj nagnjeni k okužbam spodnjih dihal zaradi motenega razvoja pljuč in imunskega sistema (5). V našem primeru je bila porodna teža novorojenčkov s pridruženo atelektazo nižja, a ne statistično značilno. Štirje bolniki so bili nedonošeni in dva sta utrpela zaplet - atelektazo.

Izsledki objavljenih raziskav o povezavi med telesno temperaturo in stopnjo bronhiolitisa si niso povsem enotni. Večina navaja, da so imeli bolniki z višjo temperaturo hujši klinični potek bolezni, daljšo hospitalizacijo, ugotavljali pa so tudi več radioloških zapletov (atelektaz, zgostitev) $(9,10)$. $V$ našem primeru se je izkazalo, da se novorojenčki $z$ atelektazo in novorojenčki brez nje po višini telesne temperature ne razlikujejo.

Čeprav številne raziskave ne podpirajo zdravljenja akutnega bronhiolitisa z antibiotiki, jih še vedno pogosto uporabljamo $v$ sklopu bolnišničnega zdravljenja bronhiolitisa (11, 12). $V$ našem primeru je antibiotično zdravljenje prejemalo sedem od osmih bolnikov s pridruženo atelektazo. Pet od omenjenih novorojenčkov je imelo klinično in radiološko potrjeno pljučnico, pri dveh od njih (edina bolnika z invazivnim predihavanjem) pa so $v$ aspiratu sapnika izolirali bakterijskega povzročitelja. Omenjena novorojenčka sta imela pridruženo tudi okužbo sečil. Eden je prejemal antibiotik zaradi 
Novorojenčki z

atelektazo

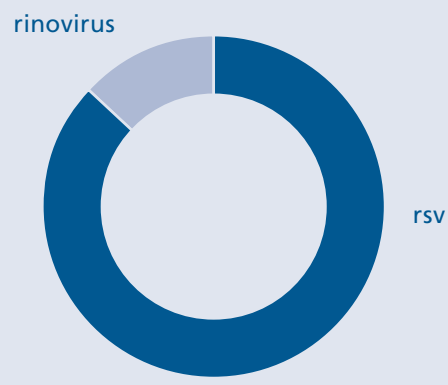

Novorojenčki brez atelektaze
SLIKA 1. VIRUSNI POVZROČITELJI PRI NOVOROJENČKIH Z ATELEKTAZO IN PRI NOVOROJENČKIH BREZ NJE.

Legenda: RSV - respiratorni sincicijski virus.
FIGURE 1. VIRAL PATHOGENS IN THE GROUP OF NEONATES WITH AND WITH OUT ATELECTASIS

Legend: RSV - respiratory syncytial virus. vnetja popka, pri enem pa je bil postavljen klinični sum na sepso. Novorojenčki brez pridružene atelektaze so antibiotično zdravljenje prejemali v statistično značilno nižjem številu (6 od 21). Od njih so imeli trije klinično sliko pljučnice, pri enem smo postavili sum na sepso, eden je imel mikrobiološko potrjeno sepso in pri enem smo sprva ugotavljali mikrobiološko potrjeno sepso s pridruženim meningitisom, kasneje še katetrsko sepso.

Povzročitelji akutnega bronhiolitisa so virusi, zato so vrednosti vnetnih kazalnikov praviloma nizke ali le zmerno povišane. Izsledki nekaterih raziskav navajajo, da je povišana vrednost CRP povezana s težjo klinično sliko bolezni, daljšo hospitalizacijo in večjo potrebo po kisiku. Za vse opazovane kazalnike vnetja velja, da na podlagi visoke vrednosti potrdimo pridruženo bakterijsko okužbo (15-17). Število levkocitov je bilo v obeh skupinah podobno, medtem ko je bila vrednost CRP višja pri bolnikih s pridruženo atelektazo, a ne statistično značilno. Višje vrednosti CRP v skupini z atelektazo lahko pojasnimo z večjim deležem pridruženih bakterijskih okužb pri teh bolnikih.

Znano je, da je moški spol dejavnik tveganja za pojavnost bronhiolitisa in tudi za težji potek $(1,2)$. Skupaj smo obravnavali štirinajst novorojenčkov ženskega spola in šestnajst novorojenčkov moškega spola. Med novorojenčki s pridruženo atelektazo je bilo več novorojenčkov moškega spola, a razlika ni bila statistično značilna.

Prenatalna kot tudi postnatalna izpostavljenost cigaretnemu dimu je znan dejavnik tveganja za težji potek bronhiolitisa $(1,2)$. $V$ naši raziskavi tega dejavnika nismo ovrednotili, saj nismo imeli podatka o kajenju za dovolj veliko število novorojenčkov.

Število dni zdravljenja s kisikom je bilo pri novorojenčkih s pridruženo atelektazo statistično značilno višje kot pri novorojenčkih brez atelektaze. Najvišja izmerjena vrednost $\mathrm{pCO}_{2}$ je bila pri novorojenčkih s pridruženo atelektazo statistično značilno višja kot pri novorojenčkih brez atelektaze.
V današnjem času je zdravljenje dihalne stiske pri novorojenčkih z neinvazivnim predihavanjem široko v uporabi. Temelji na vzpostavitvi in ohranjanju nizkotlačne razpetosti pljuč ob ohranjenem spontanem dihanju. Učinek se kaže v zmanjšanju dihalnega dela ter manjši potrebi po kisiku, endotrahealni intubaciji in invazivnem predihavanju. Uporabljamo več različnih načinov neinvazivnega predihavanja glede na različne indikacije in glede na to, kako vešče je osebje pri izvajanju (11, $13,14)$. Pri nas večinoma uporabljamo nosni CPAP.

Glede na izsledke raziskav je pri novorojenčkih z bronhiolitisom prisotnost atelektaze pomemben dejavnik tveganja za sprejem v EIT zaradi potrebe po invazivnem predihavanju $(18,19,20)$.

V naši raziskavi so novorojenčki brez pridružene atelektaze $v$ bistveno manjšem številu potrebovali neinvazivno dihalno podporo. Sedem od osmih novorojenčkov s pridruženo atelektazo je potrebovalno neinvazivno dihalno podporo, dva pa sta bila prehodno 


\begin{tabular}{|c|c|c|c|c|}
\hline Skupina & $\begin{array}{l}\text { Vrsta bakterijske } \\
\text { okužbe }\end{array}$ & $\begin{array}{l}\text { Bakterijski } \\
\text { povzročitelj }\end{array}$ & Kužnina & $\begin{array}{l}\text { Antibiotično } \\
\text { zdravljenje }\end{array}$ \\
\hline \multicolumn{5}{|c|}{ NOVOROJENČKI Z ATELEKTAZO } \\
\hline 1. & $\begin{array}{l}\text { pljučnica } \\
\text { okužba sečil }\end{array}$ & $\begin{array}{l}\text { Streptococcus } \\
\text { pneumoniae } \\
\text { Escherichia coli }\end{array}$ & $\begin{array}{l}\text { aspirat sapnika } \\
\text { urinokultura }\end{array}$ & cefotaksim, ampicilin \\
\hline 2. & pljučnica & I & I & ampicilin, gentamicin \\
\hline 3. & pljučnica & I & I & ampicilin, gentamicin \\
\hline 4. & pljučnica & l & I & ampicilin, gentamicin \\
\hline 5. & vnetje popka & I & l & $\begin{array}{l}\text { flukloksacilin, } \\
\text { gentamicin }\end{array}$ \\
\hline 6. & $\begin{array}{l}\text { pljučnica } \\
\text { okužba sečil }\end{array}$ & $\begin{array}{l}\text { Escherichia coli } \\
\text { Staphylococcus } \\
\text { aureus } \\
\text { Enterococcus } \\
\text { faecalis } \\
\text { Staphylococcus } \\
\text { aureus }\end{array}$ & $\begin{array}{l}\text { aspirat sapnika } \\
\text { urinokultura }\end{array}$ & $\begin{array}{l}\text { amoksicilin }+ \\
\text { klavulanska kislina }\end{array}$ \\
\hline 7. & sum na sepso & I & I & ampicilin, gentamicin \\
\hline \multicolumn{5}{|c|}{ NOVOROJENČKI BREZ ATELEKTAZE } \\
\hline 1. & pljučnica & I & I & ampicilin, gentamicin \\
\hline 2. & sepsa & $\begin{array}{l}\text { Streptococcus } \\
\text { gallolyticus }\end{array}$ & hemokultura & ampicilin, gentamicin \\
\hline 3. & sum na sepso & I & I & ampicilin, gentamicin \\
\hline 4. & $\begin{array}{l}\text { meningitis, sepsa } \\
\text { katetrska sepsa }\end{array}$ & $\begin{array}{l}\text { Streptococcus } \\
\text { mitis } \\
\text { Staphylococcus } \\
\text { epidermidis }\end{array}$ & $\begin{array}{l}\text { hemokultura } \\
\text { konica katetra }\end{array}$ & $\begin{array}{l}\text { penicilin G } \\
\text { vankomicin }\end{array}$ \\
\hline 5. & pljučnica & I & I & $\begin{array}{l}\text { cefotaksim, } \\
\text { flukloksacilin }\end{array}$ \\
\hline 6. & pljučnica & I & I & $\begin{array}{l}\text { amoksicilin + } \\
\text { klavulanska kislina }\end{array}$ \\
\hline
\end{tabular}

TABELA 2. VRSTA BAKTERIJSKE OKUŽBE IN IZOLIRANI BAKTERIJSKI POVZROČITELJI IZ RAZLIČNIH KUŽNIN PRI NOVOROJENČKIH, KI SO BILI ZDRAVLJENI Z ANTIBIOTIKI.

TABLE 2. TYPE OF BACTERIAL INFECTION AND ISOLATED BACTERIAL AGENTS FROM DIFFERENT ISOLATES IN THE GROUPS OF NEONATES WITH AND WITHOUT ATELECTASIS TREATED WITH ANTIBIOTICS.

\section{Zaključki}

Atelektaza je pomemben zaplet akutnega bronhiolitisa, ki pomembno vpliva na stopnjo hipoksemije in na potek bolezni. Rezultati retrospektivne analize novorojenčkov z bronhiolitisom so pokazali, da so imeli novorojenčki $z$ atelektazo bakterijsko superinfekcijo in pljučnico pogosteje kot novorojenčki brez atelektaze.

Ugotovili smo tudi, da so novorojenčki s pridruženo atelektazo dodatek kisika v vdihanem zraku ter neinvazivno ali celo invazivno dihalno podporo potrebovali dlje kot novorojenčki brez atelektaze.

$\checkmark$ prihodnje bi bilo ob velikem vsakoletnem številu novorojenčkov z akutnim bronhiolitisom smiselno zastaviti prospektivno raziskavo $v$ več zaporednih sezonah. $Z$ njo bi lahko rezultate potrdili na večjem številu bolnikov in bolj natančno opredelili dejavnike tveganja, ki jih v tokratni raziskavi nismo uspeli analizirati (npr. kajenje staršev, starost sorojencev, klinična slika itd.), ter opredelili morebitno vzročno povezavo s pridruženo atelektazo.

Literatura

1. Merkus PJFM, Hoog M, Gent R, Jongste JC. DNAse treatment for atelectasis in infants with severe respiratory syncytial virus bronchiolitis. European 
Respiratory Journal 2001; 18: 734-7.

2. Lanari M, Prinelli F, Adorni F, Di Santo S, Vandini S, Silvestri, et al. Risk factors for bronchiolitis hospitalization during the first year of life in a multicenter Italian birth cohort. Ital Journal of pediatrics 2015; 41: 40

3. Praprotnik M, Kotnik Pirš A, Zver A, Aldeco M, Lepej D, Mrvič T, et al. Novosti v obravnavi otrok z akutnim bronhiolitisom. Slov Pediatr 2018; 25: 284-98.

4. Piedra P, Stark A. Bronchiolitis in infants and children: Treatment, outcome, and prevention, 2020 April. Dosegljivo na: https://www.uptodate. com/contents/bronchiolitis-in-infants-and-children-treatment-outcome-and-prevention.

5. Park HW, Lee BS, Kim AR, Yoon HS, Kim $\mathrm{BI}$, Song ES, et al. Epidemiology of respiratory syncytial virus infection in infants born at less than thirty-five weeks of gestational age. Pediatr Infect Dis 2012; 31: 99-104.

6. Leung AK, Kellner JD, Davies HD. Respiratory syncytial virus bronchiolitis. J Natl Med Assoc 2005; 97: 1708-13

7. Sommer C, Resch B, Simões EAF. Risk factors for severe respiratory syncytial virus lower respiratory tract infection. Open Microbio J 2011; 5 (Suppl 2-M4): 144-5.

8. Knut $\varnothing$, Håvard Ove $S$, Bruun Mikalsen I. Acute bronchiolitis in infants, a review. Scand J Trauma Resusc Emerg Med 2014; 22: 23.

9. Radhi A, Barry W, Patel S. Association of fever and severe clinical course in bronchiolitis. Arch Dis Child 1999; 81: 231-4.

10. Butnariu A: Chindris AM, Giurgiu D, Leucuta A. Correlation between fever and the clinical severity of acute bronchiolitis. Pneumologia 2005; 54: 154-7.

11. Maraqa NF. Bronchiolitis. Dosegljivo na: https://emedicine.medscape.com/ article/961963-treatment.

12. Farley R, Spurling G, Eriksson L, Del Mar CB. Antibiotics for bronchiolitis in children under two years of age. Dosegljivo na: https://www. cochranelibrary.com/cdsr/doi/10.1002/14651858. CD005189.pub4/full.

13. Nosan G. Neinvazivna ventilacija v neonatologiji. Klinična neonatologija: 1953 - 2013. Dosegljivo na: http://prvikoraki.si/prvikoraki/ wp-content/uploads/2014/01/PRVI_KORAKI_60letnica-WEB.pdf.

14. Franklin D, Babl FE, Schlapbach LJ, Oakley E, Craig S, Neutze JA, et al. Randomized Trial of High-Flow Oxygen Therapy in Infants with Bronchiolitis. N Engl J Med 2018; 378: 1121-31.

15. Laham JL, Breheny PJ, Gardner BM, Bada $H$. Procalcitonin to predict bacterial coinfection in infants with acute bronchiolitis: a preliminary analysis. Pediatric Emergency Care 2014; 30: 11-5.

16. Costa S, Rocha R, Tavares M, Bonito-Vítor

A, Guedes-Vaz L. C Reactive protein and disease severity in bronchiolitis. Rev Port Pneumol 2009; 15: 55-65.

17. Fares M, Mourad S, Rajab M, Rifai N. The use of C-reactive protein in predicting bacterial co-infection in children with bronchiolitis. N Am J Med Sci 2011; 3: 152-6.

18. López Guinea A, Casado Flores J, Sobrino M, Espínola Docio B, de la Calle Cabrera T, Serrano
A, García Teresa M. Severe bronchiolitis. Epidemiology and clinical course of 284 patients. An Pediatr (Barc) 2007; 67. Dosegljivo na: https:// pubmed.ncbi.nlm.nih.gov/17692256/.

19. Hervás D, Reina J, Yañez A, del Valle JM, Figuerola J, Hervás JA. Epidemiology of hospitalization for acute bronchiolitis in children: differences between RSV and non-RSV bronchiolitis. Eur J Clin Microbiol Infect Dis 2012; 31. Dosegljivo na: https://pubmed.ncbi.nlm.nih.gov/22240853/ 20. Si-Ying $L, W u Y$, Qian $Y i$, Wang $Z$, Tang $Y$, Zhang $G$, et al. Predictive factors for failure of continuous positive airway pressure treatment in infants with bronchiolitis. Zhongguo Dang Dai Er Ke Za Zhi 2020; 22. Dosegljivo na: https://pubmed.ncbi.nlm.nih.gov/32312372/.
Anja Korošec, dr. med.

Klinični oddelek za neonatologijo

Pediatrična klinika

UKC Ljubljana, Ljubljana, Slovenija

dr. Jana Lozar Krivec, dr. med. (kontaktna oseba / contact person)

Klinični oddelek za neonatologijo

Pediatrična klinika

UKC Ljubljana

Bohoričeva 20, 1000 Ljubljana, Slovenija e-pošta: jana.lozarkrivec@kclj.si

doc. dr. Mojca Grošelj Grenc, dr. med. Klinični oddelek za neonatologijo Pediatrična klinika, UKC Ljubljana, Ljubljana, Slovenija

Prispelo / received: 29. 9. 2020

Sprejeto / accepted: 27. 3. 2021

Korošec A, Lozar Krivec J, et.al. Atelektaza kot zaplet akutnega bronhiolitisa pri novorojenčku. Slov Pediatr 2021; 28(3): 123-129. https://doi. org/10.38031/slovpediatr-2021-3-06. 